\title{
Electrophysiology and Cardiovascular Pharmacology of Mokuboito (Formula Aristolochiae): Cardiotonic and Cardioprotective Actions for Chronic Heart Failure
}

\author{
Hiroyasu Satoh* \\ Health Life Science, Shitennoji University, Habikino, Japan
}

"Corresponding author: Hiroyasu Satoh, Health Life Science, Shitennoji University, 3-2-1 Gakuenmae, Habikino ,Osaka 5838501, Japan. Tel: +81729563181, Fax:+81729566011; E-Mail: hysat@shitennoji.ac.jp

Citation: Satoh H (2017) Electrophysiology and Cardiovascular Pharmacology of Mokuboito (Formula Aristolochiae): Cardiotonic and Cardioprotective Actions for Chronic Heart Failure. Cardiolog Res Cardiovasc Med 2: 117. DOI: 10.29011/2575-7083.000017

Received Date: 06 June, 2017; Accepted Date: 28 June, 2017; Published Date: 5 July, 2017

\begin{abstract}
Cardiovascular actions of Mokuboito (Formula aristolochiae), a kind of Kampo formulations, the ingredients and the phytochemicals, were investigated. In electrophysiological experiments, Mokuboito and its main ingredient (an herb), Sinomeni Caulis et Rhizoma (SCR), enhanced the L-type $\mathrm{Ca}^{2+}$ current $\left(\mathrm{I}_{\mathrm{Ca}}\right)$ and the delayed rectifier $\mathrm{K}^{+}$current $\left(\mathrm{I}_{\mathrm{Krec}}\right.$ ), and inhibited the inwardly rectifying $\mathrm{K}^{+}$current $\left(\mathrm{I}_{\mathrm{K} 1}\right)$. Simultaneously they affected the action potential configurations, and decreased the maximum rate of depolarization. On the other hand, the phytochemicals such as sinomenine and tetrandrine inhibited the ionic currents concentration-dependently. But magnoflorine had less or no effect. In addition, sinomenine abolished dysrhythmias under $\mathrm{Ca}^{2+}$ overload conditions. In vascular experiments, sinomenine greatly dilated NE-induced vasoconstriction in 10 -weeks old rats, but the vasodilatation became weaker age-dependently. SCR showed almost the similar behaviors. On the other hand, Mokuboito constantly produced the vasodilatation in all aged rats. Thus, Mokuboito as a mixture exhibit the active cardiotonic and cardioprotective actions, independent of advance in ages. Additional prescription to the standard recommended therapy for chronic heart failure may expect to improve clinical manifestations as a complemental and alternative medicine.
\end{abstract}

Keywords: Cardiotonic Action; Complemental and Alternative Medicine; Mokuboito; Phytochemicals; Sinomeni Caulis et Rhizoma; Sinomenine; Vasodilatation

\section{Introduction}

Mokuboito (Formula aristolochiae), a kind of Kampo formulations (Japanese herbal medicine), has been used clinically for centuries in Japan. Mokuboito has been traditionally used as an indication for the patients with the symptoms including wheezing, dark complexion and deep tight pulse. It has been reported that Mokuboito improves heart failure symptoms accompanied by the decline of plasma Brain Natriuretic Peptide (BNP) concentration, and reduces the rank of NYHA classification [1]. The main ingredient (herb) of Mokuboito is Sinomeni Caulis et Rhizoma (SCR) containing the phytochemicals such as sinomenine, tetrandrine and magnoflorine, and has been applied for disturbance of body fluids and Rheumatic diseases as a pain killer [2,3].
Chronic heart failure occurs more frequently in elderly persons. Advance with age produces various physiological and pathological deleterious changes such as plaque formation in vascular systems. Simultaneously, the age-dependent alterations of receptors, ion channels and cellular signal transduction pathways cause in the endothelium and smooth muscle cells. As a result, the pharmacological effects of the drugs on cardiovascular system may be necessarily modulated along with ageing. The endotheliumdependent relaxation has been reported to be attenuated in aged rat aorta $[4,5]$. In direct in situ measurement of Nitric Oxide (NO) in rat aorta, the NO-release diminishes further in aged rats. The relaxation induced by $\mathrm{ACh}$ is impaired in the aortic rings obtained from old female rats [6]. NO-synthesis inhibitor (L-NAME) attenuates the age-dependent $\mathrm{ACh}$-induced vasodilatation. Thus, the NO-dependent vasodilatation decreases with ageing.

Satoh [7] has already shown that Mokuboito, SCR, and sinomenine (the main phytochemical), have the electropharmaco- 


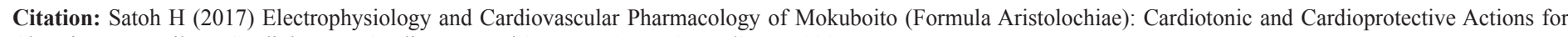
Chronic Heart Failure. Cardiolog Res Cardiovasc Med 2: 117. DOI: 10.29011/2575-7083.000017

logical actions and exert the electrophysiological effects on cardiomyocytes. As well, Mokuboito and the ingredients dilate rat aorta, due to not only endothelium-dependent mechanisms related with the activations of $\mathrm{NO}$ and $\mathrm{PGI}_{2}$, but also endothelium-independent mechanisms related with the inhibitions of $\mathrm{Ca}^{2+}$ channel, $\mathrm{Ca}^{2+}-$ activated $\mathrm{K}^{+}$channel and PK-C activities [8,9]. Thus, Mokuboito regulates the tone of blood vessels and adjusts the blood pressure and flow, possibly resulting in the improvement of the cardiac functions under the chronic heart failure $[1,10]$.

Now the characteristics of cardiovascular pharmacology of Mokuboito, the ingredients and the phytochemicals are examined, and their ameliorative pharmacological actions on chronic heart failure are discussed.

\section{Mokuboito (Formula aristolochiae)}

Mokuboito is composed of four herbal drugs

1. SCR (or Sinomenium acutum Rehder et Wilson)

2. Cinnamoni cortex [11]

3. Ginseng radix [12]

4. Gypsum

SCR is comprised of some phytochemicals such as tetrandrine, sinomenine and magnoflorine [13]. SCR has been wellknown as a modulator of body's fluid, and has been used for fluid's disturbance and Rheumatic diseases [2,14]. Sinomenine, a phytochemical of SCR, is an alkaloid [15], and exhibits antiinflammatory [16] and immuno-modulative actions [3]. Accordingly, Mokuboito has usually been also used for clinical treatment of Rheumatoid arthritis [1,17].

Cardiovascular pharmacological experiments for Mokuboito have demonstrated the effective actions for (a) hypertension $[18,19]$ and (b) proximal supra ventricular tachycardia [20-22]. Furthermore, it possesses (c) an antioxidant action [23] and (d) an anti-thrombogenic action [24]. Most recent studies demonstrate that application of Mokuboito is so effective for chronic heart failure $[25,26]$. Advance in ages alters the physiological and pharmacological functions. Mokuboito has been found to cause no or less age-related pharmacological effect, because of the multifunction and the complicated interactions induced by mixed drug [27]. The multiple pharmacological actions would compensate and maintain the lack of some responses with ageing. The actions induced by Mokuboito are exhibited as a net of the complicated interactions among numerous ingredients and phytochemicals. In our laboratory, Mokuboito possesses and maintains a more potent vasodilating action as compared with the ingredient and phytochemical alone [25].

\section{Electropharmacology of Mokuboito}

\section{On the action potential of guinea pig hearts}

In guinea pig ventricular cardiomyocytes, the current-clamp experiments were performed to examine the modulation of the action potential configuration. The modified Tyrode solution was used: $\mathrm{NaCl} 137, \mathrm{KCl} 5.4, \mathrm{CaCl}_{2} 1.8, \mathrm{MgCl}_{2}$ 1.0, $\mathrm{NaH}_{2} \mathrm{PO}_{4} 0.3$, glucose 5.0, and HEPES 5.0 (in $\mathrm{mM}$ ). The herbal medicines were dissolved with DMSO, and bath solutions with the desired concentrations were superfused at $36^{\circ} \mathrm{C}$.

Mokuboito affected the action potential configurations. The maximum rate of depolarization $\left(\mathrm{V}_{\max }\right)$ and the amplitude (APA) decreased, and the Action Potential Duration (APD) increased, as shown in Figure $1 \mathrm{~A} \& \mathrm{~B}$. SCR $(1 \mathrm{mg} / \mathrm{ml})$ decreased the $\mathrm{V}_{\text {max }}$. In the phytochemicals contained in SCR, sinomenine $(300 \mu \mathrm{M})$ caused the similar effects; the inhibitions of APA and $\mathrm{V}_{\max }$, and the prolongation of APD. Tetrandrine at 30 and $100 \mu \mathrm{M}$ prolonged the $75 \%$ repolarization of APD $\left(\mathrm{APD}_{75}\right)$ by $24.8 \pm 2.7 \%(\mathrm{n}=7, \mathrm{P}<0.01)$ and by $41.7 \pm 2.9 \%(\mathrm{n}=7, \mathrm{P}<0.001)$, respectively. The APA was reduced by $16.3 \pm 2.7 \%(\mathrm{n}=6, \mathrm{P}<0.05)$ at $100 \mu \mathrm{M}$ tetrandrine. On the other hand, magnoflorine (another phytochemical) just at $1 \mathrm{mM}$ also prolonged $\mathrm{APD}_{75}$ by $16.7 \pm 4.3 \%(\mathrm{n}=5, \mathrm{P}<0.05)$, but failed to affect other action potential parameters. These effects on the action potential configuration are roughly summarized in Figure 2 .

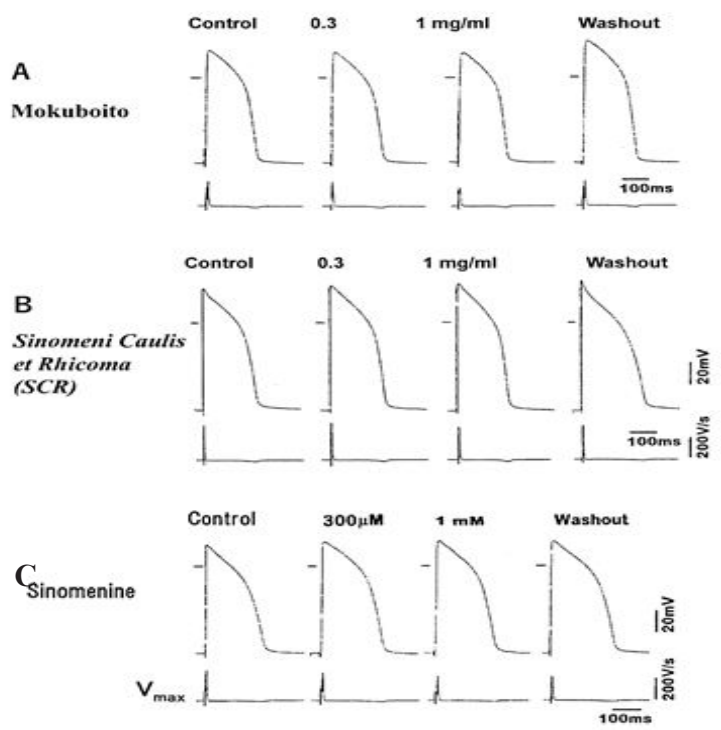

Figure 1: A: Effects of Mokuboito, B: Sinomeni caulis et rhizoma (SCR) and $\mathrm{C}$ : sinomenine on the action potentials in guinea pig ventricular cardiomyocyte. Upper panel: Action potential configurations. Lower panel: Vmax. Short lines at the left of action potential recordings represent zero $\mathrm{mV}$ level. 


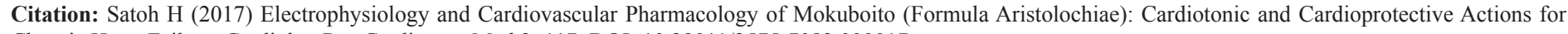
Chronic Heart Failure. Cardiolog Res Cardiovasc Med 2: 117. DOI: 10.29011/2575-7083.000017

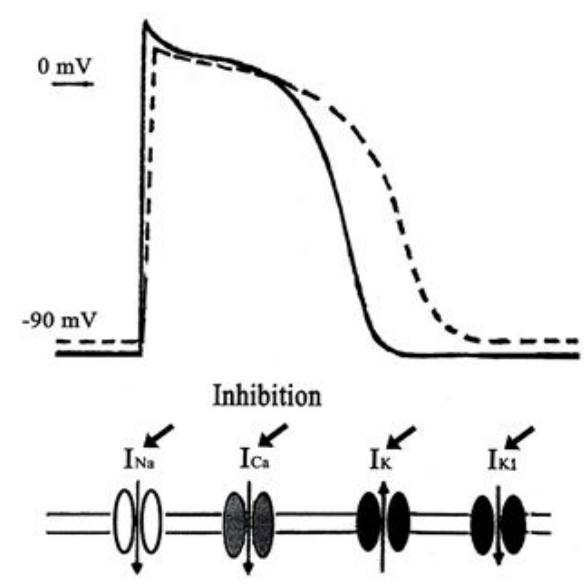

Figure 2: The superimposed action potentials in the absence and the presence of Mokuboito. The electrophysiological effects are summarized. The horizontal line indicates zero $\mathrm{mV}$.

Thus, major action of these drugs is the $\mathrm{V}_{\max }$ inhibition. Mokuboito has the slight effects on the other action potential parameters, and other ingredients also produce almost the similar responses. Simultaneously, the APA was markedly inhibited. Both the $\mathrm{V}_{\max }$ and APA inhibitions are due to the inhibitory action on the fast $\mathrm{Na}^{+}$current $\left(\mathrm{I}_{\mathrm{Na}}\right)$, indicative of a class I antiarrhythmic action. Both also lead to an inhibition in the conduction velocity and a suppression of excitability. As well, the $\mathrm{I}_{\mathrm{Na}}$ inhibition leads to greater decline of the cellular $\mathrm{Ca}^{2+}$ concentration $\left(\left[\mathrm{Ca}^{2}\right]_{\mathrm{i}}\right)$. Then, the cellular $\mathrm{Ca}^{2+}$ overload under heart diseases would be reduced.

To examine the effects on the action potential configuration of papillary muscles (multicellular preparations) in guinea pig heart, conventional microelectrode experiments were carried out. The preparations were stimulated at $1 \mathrm{~Hz}$. Mokuboito at $1 \mathrm{mg} /$ $\mathrm{ml}$ decreased the $\mathrm{V}_{\max }$ by $13.6 \pm 2.4 \%(\mathrm{n}=6, \mathrm{P}<0.05)$. The other action potential parameters were unaffected. SCR $(0.3$ and $1 \mathrm{mg} /$ $\mathrm{ml}$ ) had no or less effects on the action potential configuration. At $1 \mathrm{mg} / \mathrm{ml}$, only the $\mathrm{V}_{\text {max }}$ decreased by $10.0 \pm 2.1 \%(\mathrm{n}=5, \mathrm{P}<0.05)$. The $50 \%$ and $90 \%$ repolarizations of $\mathrm{APD}\left(\mathrm{APD}_{50}\right.$ and $\left.\mathrm{APD}_{90}\right)$ at $1 \mathrm{mg} / \mathrm{ml}$ decreased by $5.4 \pm 3.6 \%(\mathrm{n}=6)$ and $9.2 \pm 2.8 \%(\mathrm{n}=$ 6 ), respectively, but not significantly. The APA was also tended to decrease, and the resting potential (RP) was unaffected. A washout for 15-20 min recovered to almost $90 \%$ of control values.

Sinomenine $(100 \mu \mathrm{M}$ to $1 \mathrm{mM})$ showed the inhibitory effects on the action potentials of papillary muscles Figure 1C. The $\mathrm{V}_{\max }$ was inhibited by $20.0 \pm 2.4 \%(\mathrm{n}=6, \mathrm{P}<0.05)$ at $300 \mu \mathrm{M}$ and by $32.1 \pm 3.3 \%(\mathrm{n}=6, \mathrm{P}<0.01)$ at $1 \mathrm{mM}$. Sinomenine $(1 \mathrm{mM})$ also decreased the APA, but did not cause to significant extent (by 0.9 $\pm 2.1 \%, \mathrm{n}=5$ ). Sinomenine at $300 \mu \mathrm{M}$ increased the $\mathrm{APD}_{75}$ by $24.9 \pm 3.5 \%(\mathrm{n}=6, \mathrm{P}<0.05)$ and at $1 \mathrm{mM}$ by $43.7 \pm 3.3 \%(\mathrm{n}=$ $6, \mathrm{P}<0.001)$. The RP was unaffected. Tetrandrine at 10 to $300 \mu \mathrm{M}$ caused the concentration-dependent inhibitory effects on the action potentials. The APA decreased by $18.3 \pm 2.2 \%(\mathrm{n}=7, \mathrm{P}<0.05)$ at $300 \mu \mathrm{M}$, but not at the lower concentrations. Simultaneously the $\mathrm{V}_{\max }$ significantly decreased at higher concentrations than $30 \mu \mathrm{M}$; by $35.8 \pm 2.4 \%(\mathrm{n}=7, \mathrm{P}<0.001)$ at $300 \mu \mathrm{M}$. Tetrandrine tended to decrease both the $\mathrm{APD}_{50}$ and the $\mathrm{APD}_{90}$. The RP was also unaffected. Magnoflorine had less or no effect on any action potential parameters.

As a result, Mokuboito and the ingredients at even acute administrations exert the potent electropharmacological actions and produce the cardioprotections. However, there are some different actions in myocyte and multicellular preparations. Significant effects on the APD are not caused (but are tended to shorten) in the papillary muscles (multicellular preparations), whereas the APD is prolonged in the cardiomyocytes. In both specimens, the great $\mathrm{V}_{\max }$ inhibition is produced. Mokuboito as a mixture should exhibit the APD shortening due to the $\mathrm{V}_{\text {max }}$ inhibition, but the responses are controversial. The phenomena are consistent with our previous reports $[28,29]$. Several possibilities for this discrepancy may exist. One is no intercellular space in the cardiomyocytes, and thereby the physiological relationship between cell and cell (including such as a gap junction) is absent [30-32]. The existence of intercellular space would be a key for whole heart to maintain the functions. Another may be a difference of sensitivity to the drugs. The effective responses were produced at relatively lower concentrations in the myocytes than multicellular preparations. Using higher concentrations to the myocytes, there might be some limitations for the occurrence of cell damages.

Interestingly, application of $300 \mu \mathrm{M}$ sinomenine suppressed and completely abolished the abnormal action potentials (the dysrhythmias) induced by cellular $\mathrm{Ca}^{2+}$ overload Figure 3. In high extracellular $\mathrm{Ca}^{2+}$ solution $(5.4 \mathrm{mM})$, the abnormal action potentials elicited by triggered activities occurred irregularly, despite the fact that the papillary muscle of guinea pig heart was constantly stimulated at $1 \mathrm{~Hz}$. At even acute administrations, thus, these drugs greatly exhibit the electropharmacological actions and cardioprotections. Therefore, Mokuboito and its ingredients may improve the cardiac functions such as the antiarrhythmic and cardiotonic actions under chronic heart failure. 
Citation: Satoh H (2017) Electrophysiology and Cardiovascular Pharmacology of Mokuboito (Formula Aristolochiae): Cardiotonic and Cardioprotective Actions for Chronic Heart Failure. Cardiolog Res Cardiovasc Med 2: 117. DOI: 10.29011/2575-7083.000017

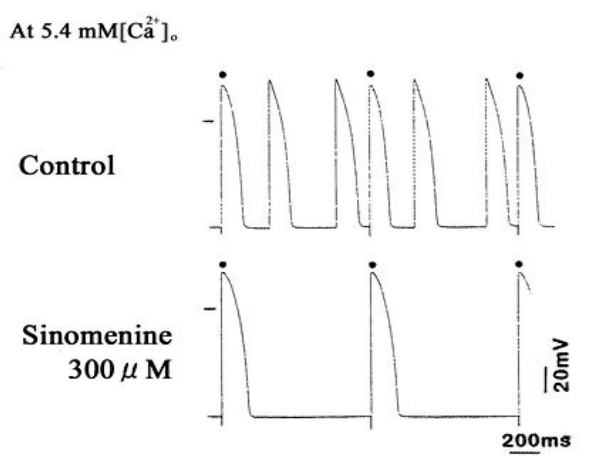

Figure 3: Antiarrhythmic action of sinomenine. Dysrhythmias occurred at $5.4 \mathrm{mM}\left[\mathrm{Ca}^{2+}\right]_{0}$. Dots above the action potential recordings are represented the regular rhythms induced by $1 \mathrm{~Hz}$ stimulation. The horizontal line indicates zero $\mathrm{mV}$.

\section{On the ionic channel currents of cardiomyocytes}

In the voltage-clamp experiments using guinea pig ventricular cardiomyocytes, Figure 4 shows the modulation by Mokuboito of the ionic currents. Test pulses were applied from -120 to $60 \mathrm{mV}$ from a holding potential of $-30 \mathrm{mV}$. The average capacitance was $84.1 \pm 2.4 \mathrm{pF}(\mathrm{n}=23)$. Mokuboito at $1 \mathrm{mg} / \mathrm{ml}$ enhanced the L-type $\mathrm{Ca}^{2+}$ current $\left(\mathrm{I}_{\mathrm{Ca}}\right)$ at $0 \mathrm{mV}$ by $157.3 \pm 5.5 \%(\mathrm{n}=6, \mathrm{P}<0.001)$ and the delayed rectifier $\mathrm{K}^{+}$current $\left(\mathrm{I}_{\mathrm{Krec}}\right)$ at $60 \mathrm{mV}$ by $262.1 \% \pm 7.3 \%(\mathrm{n}=$ $6, \mathrm{P}<0.001)$, and inhibited the inwardly rectifying $\mathrm{K}^{+}$current $\left(\mathrm{I}_{\mathrm{K} 1}\right)$ at $-120 \mathrm{mV}$ by $9.7 \pm 2.1 \%(\mathrm{n}=6, \mathrm{P}<0.05)$. The enhancement is responsible for the stimulation of $\beta$-adrenergic receptor [33]. SCR at $1 \mathrm{mg} / \mathrm{ml}$ had almost the similar responses; the increases in $\mathrm{I}_{\mathrm{Ca}}$ current at $30 \mathrm{mV}$ by $158.3 \pm 7.1 \%(\mathrm{n}=6, \mathrm{P}<0.01)$ and $\mathrm{I}_{\text {Krec }}$ at 60 $\mathrm{mV}$ by $257.6 \pm 7.1 \%(\mathrm{n}=6, \mathrm{P}<0.01)$, and the inhibition of $\mathrm{I}_{\mathrm{K} 1}$ at $-120 \mathrm{mV}$ by $10.3 \pm 2.4 \%(\mathrm{n}=6, \mathrm{P}<0.05)$ Figure 5 .

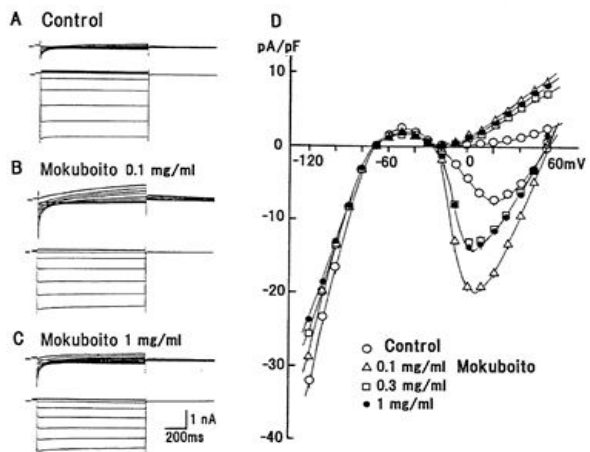

Figure 4: Effect of Mokuboito on the ionic channel current. A: Current traces in control. B-C: Current traces in Mokuboito 0.1 and $1 \mathrm{mg} / \mathrm{ml}$. Test pulses are applied from $60 \mathrm{mV}$ to $-120 \mathrm{mV}$. The holding potential is -30 $\mathrm{mV}$. The horizontal line indicates zero current level. D: Current-voltage relationships as the current density for the $\mathrm{Ca}^{2+}$ current, the delayed rectified $\mathrm{K}^{+}$current and the inwardly rectifying $\mathrm{K}^{+}$current. Symbols used are control (open circles), $0.1 \mathrm{mg} / \mathrm{ml}$ (triangles), $0.3 \mathrm{mg} / \mathrm{ml}$ (squares) and 1 $\mathrm{mg} / \mathrm{ml}$ (filled circles) of Mokuboito.
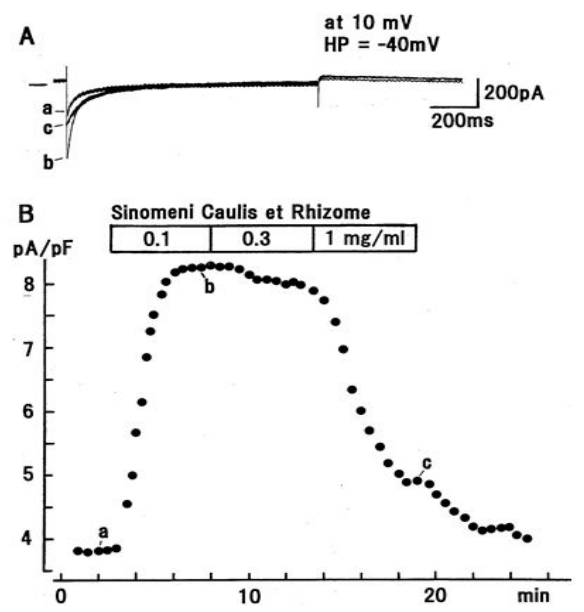

Figure 5: Effect of Sinomeni caulis et rhizoma (SCR) on the L-type $\mathrm{Ca}^{2+}$ channel current. A: Superimposed current traces. B: Time-dependent changes in the current traces in SCR 0.1, 0.3 and $1 \mathrm{mg} / \mathrm{ml}$. Test pulses are applied to $10 \mathrm{mV}$. The holding potential is $-40 \mathrm{mV}$. The horizontal line indicates zero current level.

Sinomenine (a phytochemical) at $300 \mu \mathrm{M}$ inhibited the $\mathrm{I}_{\mathrm{Ca}}$ at $0 \mathrm{mV}$ by $12.3 \pm 2.5 \%(\mathrm{n}=6, \mathrm{P}<0.05)$, and at $1 \mathrm{mM}$ by $18.2 \pm$ $2.1 \%(\mathrm{n}=6, \mathrm{P}<0.05)$. Similarly, at $1 \mathrm{mM}$, the $\mathrm{I}_{\text {Krec }}$ at $60 \mathrm{mV}$ was inhibited by $16.2 \pm 2.6 \%(\mathrm{n}=6, \mathrm{P}<0.05)$, and the $\mathrm{I}_{\mathrm{K} 1}$ at $-120 \mathrm{mV}$ was inhibited by $47.2 \pm 3.8 \%(\mathrm{n}=6, \mathrm{P}<0.01)$. Tetrandrine ( 30 $100 \mu \mathrm{M})$ also inhibited markedly the ionic currents concentrationdependently [34]. The $\mathrm{I}_{\mathrm{Ca}}$ at $10 \mathrm{mV}$ decreased by $28.1 \pm 2.5 \%(\mathrm{n}=$ $6, \mathrm{P}<0.05)$ at $100 \mu \mathrm{M}$ and by $55.9 \pm 2.7 \%(\mathrm{n}=6, \mathrm{P}<0.01)$ at 300 $\mu \mathrm{M}$. Simultaneously, the $\mathrm{I}_{\text {Krec }}$ at $60 \mathrm{mV}$ also decreased by $8.6 \pm 1.4$ $\%(\mathrm{n}=6, \mathrm{P}>0.05)$ at $100 \mu \mathrm{M}$ and by $13.2 \pm 2.5 \%(\mathrm{n}=6, \mathrm{P}<0.05)$ at $300 \mu \mathrm{M}$, but not significantly at lower concentrations. Liu et al. [35] have shown that tetrandrine inhibits both $\mathrm{L}$ - and T-type $\mathrm{Ca}^{2+}$ channel currents. The $\mathrm{I}_{\mathrm{Ca}}$ inhibitions strongly decline the $\left[\mathrm{Ca}^{2+}\right]_{\mathrm{i}}$. The $\mathrm{V}_{\max }$ inhibition means the depression of the $\mathrm{I}_{\mathrm{Na}}$ current, leading to the $\left[\mathrm{Ca}^{2+}\right]_{\mathrm{i}}$ reduction and also generally the APD shortening. But the $\mathrm{I}_{\mathrm{Krec}}$ decrease might greatly lead to the APD prolongation. Magnoflorine had less or no effect on the action potential parameters, and all the ionic currents did not also affect significantly; at $1 \mathrm{mM}$, the $\mathrm{I}_{\mathrm{Ca}}$ at $10 \mathrm{mV}$ by $-7.8 \pm 2.8 \%(\mathrm{n}=5)$, the $\mathrm{I}_{\mathrm{Krec}}$ at $60 \mathrm{mV}$ by $-5.6 \pm 2.2 \%(\mathrm{n}=5)$, and the $\mathrm{I}_{\mathrm{K} 1}$ at $-120 \mathrm{mV}$ by $-2.9 \pm 2.0 \%(\mathrm{n}$ $=5$ ). At $20 \mathrm{~min}$ after washout, these responses were recovered to almost the control.

Accordingly, the cardiac electropharmacological actions of both Mokuboito and SCR are the $\mathrm{I}_{\mathrm{Ca}}$ and $\mathrm{I}_{\mathrm{Krec}}$ enhancements, and the $\mathrm{I}_{\mathrm{K} 1}$ inhibition Figure 2. However, the ingredients (the phytochemicals) inhibit all the currents (the $\mathrm{I}_{\mathrm{Ca}}, \mathrm{I}_{\mathrm{Krec}}$ and $\mathrm{I}_{\mathrm{K} 1}$ ). At even acute administrations, thus, Mokuboito and the ingredients exert the marked electropharmacological actions, and thereby produce the cardiotonic and cardioprotective actions. Therefore, Mokuboito may improve the cardiac functions under chronic heart failure. 


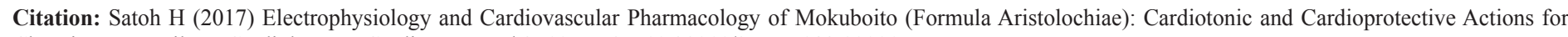
Chronic Heart Failure. Cardiolog Res Cardiovasc Med 2: 117. DOI: 10.29011/2575-7083.000017

\section{Vascular pharmacology of Mokuboito}

The comparative vasodilating actions among Mokuboito, SCR and sinomenine were examined using different aged rats. The ring strips of rat aorta were pretreated with $5 \mu \mathrm{M} \mathrm{NE}$. The modified Krebs-Henseleit solution was, in mM: $118 \mathrm{NaCl}, 4.6 \mathrm{KCl}, 1.2 \mathrm{Mg}$ $\mathrm{SO}_{4}, 1.2 \mathrm{KH}_{2} \mathrm{PO}_{4}, 11.1$ glucose, $27.2 \mathrm{NaHCO}_{3}, 0.03$ ethylne glycol-O, O'-bis (2-aminoethyl)-N,N,N',N'-tetraacetic acid (EGTA), and $1.8 \mathrm{CaCl}_{2}$. The drugs used were dissolved with DMSO. The chamber solution was kept at 36.5$)^{\circ} \mathrm{C}$ and oxygenated with $95 \%$ $\mathrm{O}_{2}$ and $5 \% \mathrm{CO}_{2}$.

Mokuboito exerted the vasodilatation in all aged rats, but inversely at low concentrations exhibited the vasoconstriction in higher aged rats Figure 6 . Mokuboito at $3 \mathrm{mg} / \mathrm{ml}$ dilated the NEinduced constriction by $98.9 \pm 2.8 \%(\mathrm{n}=7, \mathrm{P}<0.01)$ in 10 -weeks and by $97.5 \pm 13.5 \%(n=6, P<0.01)$ in 65 -weeks old rats. Sinomenine at $100 \mu \mathrm{M}$ dilated the vasoconstriction by $68.8 \pm 5.2 \%(\mathrm{n}=$ $6, \mathrm{P}<0.01)$ in 10 -weeks old rats, but only by $18.6 \pm 1.5 \%(\mathrm{n}=6$, $\mathrm{P}<0.01$ ) in 65 -weeks old rats. SCR at $0.3-3 \mathrm{mg} / \mathrm{ml}$ showed only vasodilatations in 10- and 35 -weeks old rats, and at $3 \mathrm{mg} / \mathrm{ml}$ by $96.7 \pm 4.8 \%(\mathrm{n}=7, \mathrm{P}<0.01)$ in 10 -weeks old rats. In 65 -weeks old rats, however, SCR at low concentrations $(0.03-0.3 \mathrm{mg} / \mathrm{ml})$ also constricted the aorta. The vasodilatation induced by $3 \mathrm{mg} / \mathrm{ml} \mathrm{SCR}$ was attenuated to $46.0 \pm 5.7 \%(\mathrm{n}=6, \mathrm{P}<0.01)$. The dilatation is not only due to the endothelium-dependent mechanisms (due to the activations of $\mathrm{NO}$ and $\mathrm{PGI}_{2}$ ), but also due to the modulation of $\mathrm{Ca}^{2+}$ channel, $\beta$-adrenoceptor and PK-C Activity Table $1[8,9]$. Thus, Mokuboito regulates the tone of blood vessels and adjusts the blood pressure and flow.

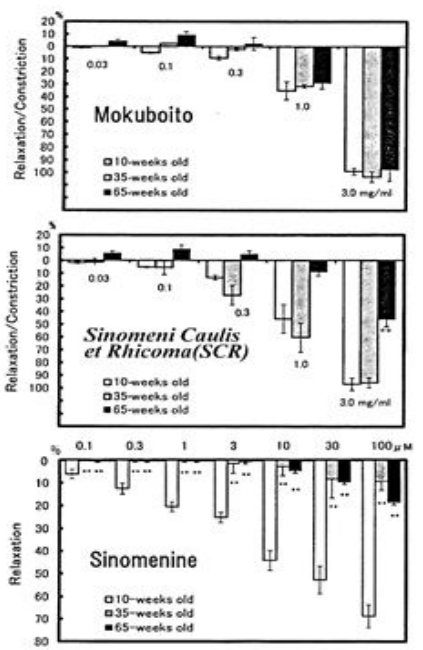

Figure 6: Age-related vasodilatations induced by Mokuboito, Sinomeni caulis et rhizoma (SCR) and sinomenine. The upper part from zero line on each panel indicates the contraction, and the lower indicates the relaxation. 10-weeks old rats are represented by white column, 35-weeks old rats by grey column and 65 -weeks old rats by black column. Values (\%) represent mean \pm S.E.M. ${ }^{* *}: \mathrm{P}<0.01$, with respect to the values of 10 -weeks old rats.

\begin{tabular}{|c|c|c|c|c|c|c|}
\hline & $\begin{array}{c}\text { NOS } \\
\text { stimu- } \\
\text { lation }\end{array}$ & $\begin{array}{c}\mathbf{P G I}_{2} \\
\text { syn- } \\
\text { thesis } \\
\text { stimu- } \\
\text { lation }\end{array}$ & $\begin{array}{c}\mathbf{C a}^{2+} \\
\text { chan- } \\
\text { nel } \\
\text { inhibi- } \\
\text { tion }\end{array}$ & $\begin{array}{c}\text { PK-C } \\
\text { inhibi- } \\
\text { tion }\end{array}$ & $\begin{array}{c}\boldsymbol{\alpha}^{-} \\
\text {stimula- } \\
\text { tion }\end{array}$ & $\begin{array}{c}\boldsymbol{\beta} \text {-stim } \\
\text { ulation }\end{array}$ \\
\hline $\begin{array}{c}\text { Moku } \\
\text { boito }\end{array}$ & + & + & + & + & + & + \\
\hline $\begin{array}{c}\text { Si- } \\
\text { nomeni } \\
\text { Caulis } \\
\text { et Rhi- } \\
\text { zoma I } \\
\text { (SCR) }\end{array}$ & + & + & + & + & + & \pm \\
\hline $\begin{array}{c}\text { Si- } \\
\text { nome- } \\
\text { nine }\end{array}$ & + & + & + & + & - & + \\
\hline
\end{tabular}

Table 1: Vascular pharmacology of Mokuboito and the ingredients.

Sinomenine produces the endothelium-dependent vasorelaxation via $\mathrm{NO}$ and $\mathrm{PGI}_{2}$ releasing from endothelium. NOS activation and $\mathrm{PGI}_{2}$ release are caused via the $\left[\mathrm{Ca}^{2+}\right]_{\mathrm{i}}$ elevation in endothelium cells $[5,6,36]$. Thus, sinomenine would increase $\left[\mathrm{Ca}^{2+}\right]$ in endothelium cells and then, activate NOS activity and PGI release, as reported previously [30]. For the endothelium-independent mechanisms, sinomenine causes the great vasorelaxation via modulation of $\mathrm{Ca}^{2+}$ channels and PK-C activity in vascular smooth muscle cells. The contraction/relaxation systems are regulated by the ion channels and the receptors, and also by the intracellular signal conductions [37-40]. Actually, sinomenine adjusts the contraction/relaxation systems mediated through the modulation of $\mathrm{Ca}^{2+}$ and $\mathrm{Na}^{+}$channels, delayed rectifier $\mathrm{K}^{+}$channels, and $\mathrm{Ca}^{2+}$-activated $\mathrm{K}^{+}\left(\mathrm{K}_{\mathrm{Ca}}\right)$ channel, accompanied with the activation of PK-C [9]. In addition, the $\beta$-adrenoceptor stimulation induced by Mokuboito and SCR also potentiates the dilatation of vascular smooth muscle cells.

Advance in ages causes numerous physiological and pathological deleterious changes such as plaque formation in vascular systems. Simultaneously, the age-dependent alterations of ion channels and signal transduction pathways may be caused in both the endothelium and the smooth muscle cells. It has been reported that the inhibitory effect of a $\mathrm{Ca}^{2+}$ channel blocker on the NE-induced constriction decreases along with ageing of 3- to 10-weeks old, whereas it increases with ageing of 10 - to 40 -weeks old. The endothelium-dependent relaxation is reduced with ageing [4]. LNAME (a NO-synthesis inhibitor) attenuates the ACh-induced vasodilatation with ageing, indicative of the age-related reduction of the NO-dependent vasodilatation $[8,9]$. Also, the vasorelaxation mediated by $\beta$-adrenoceptor stimulation decreases with ageing in rat aorta and various vascular beds of many species [41,42]. In our 


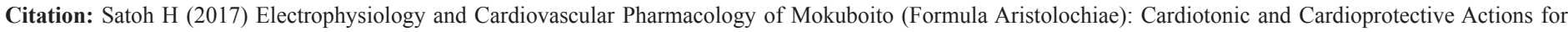
Chronic Heart Failure. Cardiolog Res Cardiovasc Med 2: 117. DOI: 10.29011/2575-7083.000017

studies, Mokuboito, SCR and sinomenine by themselves had the potent vasodilating actions. SCR- and sinomenine-induced vasodilatations decreased along with ageing, whereas Mokuboito as a mixture had less or no effect on the age-dependent attenuation in any aged rats [27]. Herbal drugs (mixter-mixter) including plenty ingredients maintain more effective actions for higher aged rats $[30,43]$. Chronic heart failure occurs more frequently in elderly persons. Therefore, the marked vasodilatation supports the cardiotonic and cardioprotective actions, and contributes to the reductions both after load and preload under the chronic heart failure.

\section{Cardiovascular effects on chronic heart failure}

The clinical therapeutic methods of chronic heart failure are (a) reducing the workload of heart, (b) protection of cardiomyocytes and (c) restriction and control of waters and sodium. The therapeutic effects of Mokuboito are produced by the intricate mechanisms induced by the large number of herbs (ingredients) and phytochemicals containing in Mokuboito. It has been generally considered that a single dose of Kampo medicine does not produce any pharmacological activities, but the repeated doses for long period of administration produce ameliorative effects. However, our studies indicate that even acute single administration can produce the marked actions on the ionic channel currents and the action potentials. In cardiac pharmacological experiments, Mokuboito increases the sinus rate and enhances the developed tension in isolated canine heart [44]. In our voltage-clamp experiments, Mokuboito and SCR markedly enhanced the $\mathrm{I}_{\mathrm{Ca}}$ and the $\mathrm{I}_{\mathrm{Krec}}$ in ventricular cardiomyocytes, and also in isolated sino-atrial nodal cells. Possibly these enhancements are produced by the stimulation of $\beta$-adrenoceptors on cardiac cell membrane [33]. Mokuboito contains further Cinnamomi cortex and Gypsum fibrosum which may release cathecholamines [13].

Mokuboito and the ingredients produce the marked effects on the action potential and the underlying ionic channel currents, resulting in clinical modulation of Electrocardiogram (ECG). As a kind of phytochemicals, tetrandrine has been reported to possess the cardiac electropharmacological actions [45,46]. Tetrandrine inhibits the voltage-dependent $\mathrm{Ca}^{2+}$ channel on cardiac cell membrane, and depresses the heart rate and the contractility $[34,35,47]$. Also, sinomenine has been found to decline the blood pressure [48]. Sinomenine and magnoflorine also exert anti-allergic and anti-histamine actions [16,49-51].

Actually, sinomenine blocked the dysrhythmias induced by triggered activities under the $\mathrm{Ca}^{2+}$ overload. Tetrandrine also exhibits antiarrhythmic actions and protects ischemic-reperfusion injury $[52,53]$. Furthermore, the $\mathrm{I}_{\mathrm{K} 1}$ inhibition induced by Mokuboito and the ingredients depolarizes the membrane potential and stabilizes the cell membrane, which plays a role for antiarrhythmic actions. The RP is not modified by Mokuboito and the ingredients. The change in RP may not have been apparent because the RP (at around $-80 \mathrm{mV}$ ) is quite close to the $\mathrm{E}_{\mathrm{K}}$ of cardiac cells. Anyways, tetrandrine and sinomenine possess potent cardioprotective actions on heart cells, due to the active modulations of the ionic channel currents (such as $\mathrm{I}_{\mathrm{Ca}}, \mathrm{I}_{\mathrm{Krec}}, \mathrm{I}_{\mathrm{K} 1}$ and $\mathrm{I}_{\mathrm{Na}}$ ) under the disease conditions.

Under the ischemia and heart failure, the cellular $\mathrm{Ca}^{2+}$ overload of heart muscles has been well known to elicit some arrhythmias and dysfunctions [28,29]. Sinomenine possesses the suppressive actions for dysrhythmias. The regulation of $\mathrm{Ca}^{2+}$ influx reduces the $\mathrm{Ca}^{2+}$ overload in cardiomyocytes and produces the cellular protection [54]. Therefore, sinomenine restrains the cell damages of heart muscles by means of the decline of $\left[\mathrm{Ca}^{2+}\right]_{i}$, and as a result, can exert the great cardioprotective actions. The cardioprotective actions of sinomenine on acute myocardial ischemia have already been demonstrated. Reperfusion injury is induced by ligating the rat left coronary artery for $15 \mathrm{~min}$ and reopening [52]. Under the conditions, sinomenine inhibits the incidence of arrhythmias and reduces $\left[\mathrm{Ca}^{2+}\right]_{\mathrm{i}}$ concentration $[48,55]$ quite consistent with our results.

Not only Mokuboito and SCR (comprised of multiple phytochemicals), but also sinomenine (a phytochemical) exhibit the strong vasodilating actions. The vascular pharmacological effects of just single phytochemical are greatly attenuated in advance with ageing. On the other hand, Mokuboito and SCR decrease the age-dependent attenuation of vasodilating action. Sinomenine has various vasodilating mechanisms above mentioned, contributing to the regulation of the preload and afterload of cardiovascular systems. The vasodilating action is one of the great useful tools for heart failure. Therefore, sinomenine-induced vasodilating action can improve cardiac functions by the reduction of workload under heart failure. Moreover, Mokuboito (a mixture) maintains the pharmacological actions with ageing. The plenty ingredients and phytochemicals contribute to the Mokuboito-induced vasodilatation via their interactions. Increasing the number of herbal ingredients (and phytochemicals) can maintain the ameliorative effects in elder rats, presumably due to the compensation each by each of the decay of pharmacological sensitivity. For elder persons, therefore, the mixture drugs comprised of many herbs (ingredients) such as a Kampo medicine exert more effective actions [56,57].

On the other hand, main electropharmacological effect of Mokuboito and SCR is the $\mathrm{I}_{\mathrm{Ca}}$ enhancement, but that of phytochemicals such as sinomenine and tetrandrine is the $\mathrm{I}_{\mathrm{Ca}}$ inhibition [56]. The interactions among the ingredients and phytochemicals play an important role for the pharmacological actions of herbal medicines. Therefore, the complex interactions produce more effective pharmacological actions of Mokuboito, according with less or no age-dependent alterations. Addition of Gypsum exaggerates the vasodilatation in elder rats.

Under the $\mathrm{Ca}^{2+}$ overload conditions such as ischemia and heart failure, Mokuboito exhibits the cardiotonic and cardiopro- 


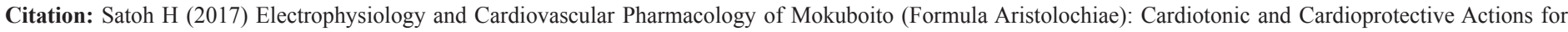
Chronic Heart Failure. Cardiolog Res Cardiovasc Med 2: 117. DOI: 10.29011/2575-7083.000017

tective actions and the vasodilatation. Clinical application of Miokuboito decreases plasma BNP concentration from approximately 800 to $200 \mathrm{pg} / \mathrm{ml}$ significantly and reduces the afterload of right heart $[25,26,58,59]$. Mokuboito has been known effective against hypertension [18-20]. Mokuboito-induced ameliorative actions have also been observed in our experiments. The vasodilating mechanisms would be due to the inhibition of $\mathrm{Ca}^{2+}$ channel and the modulation of excitation-contraction coupling, possibly mediated through many cellular signal transductions. The pharmacokinetics and tissue distribution of sinomenine in rats have been reported $[55,60]$. Sinomenine achieves high bioavailability (about 80\%) by oral administration of $90 \mathrm{mg} / \mathrm{kg}$. At $45 \mathrm{~min}$ later, sinomenine is found widely in internal organs such as kidney, liver, lung, spleen, heart, brain and testis. Sinomenine is metabolized and eliminated by kidney and liver. $\mathrm{T}_{\max }$ is $39.5 \pm 8.49 \mathrm{~min}, \mathrm{C}_{\max }$ is $13.89 \pm 4.29$ $\mu \mathrm{g} / \mathrm{ml}, \mathrm{T}_{1 / 2 \mathrm{~A} \text { phase }}$ is $61.28 \pm 53.62 \mathrm{~min}, \mathrm{AUC}_{0-\mathrm{t}}$ is $2331.53 \pm 1172.77$ $\mu \mathrm{g}-\mathrm{min} / \mathrm{ml}$, and $\mathrm{C}_{\mathrm{L}}$ is $42.95 \pm 14.4 \mathrm{ml} / \mathrm{min}$ per $\mathrm{kg}$.

Clinically, therefore, when the symptoms fail to be well improved by standard recommended therapies, addition of Mokuboito would be much expected to improve the symptoms. Moreover, when the thrapeutic limitation by several side effects induced by western medicines exist, Kampo medicines such as Goreisan (Pulvis quinque-hystericorum) and Saireito (Formula hoelen et bupleuri) as well as Mokuboito may also be more effective for chronic heart failure.

\section{Conclusion}

The pharmacological characteristics of Mokuboito are mainly the cardiotonic and the protective actions, and are also the great vasodilating action. These profitable actions are responsible for the modulation of not only ionic channel currents, $\beta$-adrenoceptor receptor and PK-C, but also endothelial cells and vascular muscle. Furthermore, SCR possesses a diuretic action, and can reduce both the preload and the afterload. SCR has been clinically applied for disturbance of body fluids and Rheumatic diseases [12]. Along with ageing, Mokuboito does not decrease and maintain the vasodilating action, although sinomenine (phytochemical) strongly declines it. Moreover, addition of Gypsum produces stronger vasodilatation in elder rats.

The age-related alterations would be responsible for physiological and anatomical reductions such as receptors, ionic channels and cellular signal transductions. Also, advanced ages elicit the decline in the sensitivity to drugs. However, Kampo medicine (mixter-mixter) maintains the pharmacological effects with ageing (but not fully). From our studies, Kampo medicine keeps the balance, and can produce either vasoconstriction or vasodilatation, according to the pathophysiological conditions [i.e., the initial (previous) tension of vessels]. In final, additional prescription of Mokuboito to the standard recommended therapy for chronic heart failure may expect to improve clinical manifestations as a complemental and alternative medicine. Extensive experiments are needed to elucidate the unknown and detailed mechanisms for pharmacology of Mokuboito.

\section{References}

1. Yakubu S, Kinoshita Y, Arakawa Y, Takahashi M, Kitanaka S (2002) Clinical evaluation of Mokuboito (Mu-Fang-Yi-Tang): A Japanese and Chinese traditional medicine for heart failure. J Trad Med 19: 159-163.

2. Yamasaki H (1976) Pharmacology of sinomenine, an anti-rheumatic alkaloid from Sinomenium acutum. Acta Med Okayama 30: 1-20.

3. Liu L, Buchner E, Beitze D, Schmidt-Weber CB, Kaever V, et al. (1996) Amelioration of rat experimental arthritides by treatment with the alkaloid sinomenine. Internat J Immunopharmacol 18: 529-543.

4. Tschudi MR, Barton M, Bersinger NA, Moreau P, Cosentino F, et al. (1996) Effect of age on kinetics of nitric oxide release in rat aorta and pulmonary artery. J Clin Invest 98: 899-905.

5. Quignard JF, Feleton M, Thollon C (1999) Pottasium ions and endothelium-derived hyperpolarizing factor in guinea-pig carotid and porcine coronary arteries. Br J Pharmacol 127: 27-37.

6. Busse R, Fichter H, Luckhoff A (1998) Hyperpolarizaion and increased free calcium in acethylcholine-stimulated endothelium cells. Am J physiol 255: H965-969.

7. Satoh H (2005) Electropharmacology of Sinomeni caulis et rhizome and its constituents in cardiomyocytes. Am J Chin Med 33: 967-979.

8. Nishida S, Satoh H (2006) In vitro pharmacological actions of sinomenine on the smooth muscle and the endothelial cell activity in rat aorta. Life Sci 79: 1203-1206.

9. Nishida S, Satoh H (2007) Vascular pharmacology of Mokuboito (MuFang-Yi-Tang) and its constituents on the smooth muscle and the endothelium in rat aorta. Evi Comp Alter Med 4: 335-341.

10. Shuji Y, Kinoshita Y, Arakawa Y (2002) Clinical evaluation of Mokuboito (Mu-Fang-Yi-Tang): a Japanese and Chinese traditional medicine for heart failure. J Trad Med 19: 159-163.

11. Kashihara Y, Goto H, Shimada Y, Sekiya N, Yang Q, et al. (2002) Inhibitory effects of Cinnamomi cortex and cinnamaldehyde on oxygenderived free radical-induced vasocontraction in isolated aorta of spontaneously hypertensive rats. J Trad Med 19: 51-57.

12. Fukuda K, Kido T, Miura N, Yamamoto M, Komatsu Y (1995) Increase in nitric oxide synthase and cyclic GMP in vascular smooth muscle cells by treatment with aqueous extracts of Astragali radix, ginsen radix and scutellariae radix. J Trad Med 12: 38-44.

13. Zhon J, Xie G, Yan X (2003) Molecular structures, natural sources and applications. In: Traditional Chinese Medicine, $2^{\text {nd }}$ Ed, Milne GWA (Ed)., New York: Ashugate.

14. Liu L, Riese J, Resch K, Kaever V (1994) Impairment of macropharge eicosanoids and nitric oxide production by alkaloid from Sinomenium acutum. Arzneimit Forsch 44: 1223-1226.

15. Mark W, Schneeberger S, Seiler R (2003) Sinomenine blocks tissue remodeling in a rat model of chronic cardiac allograft rejection. Transplantation 15: 940-945

16. Liu L, Resch K, Kaever V (1994) Inhibition of limphocyte proliferation by the anti-arthritic drug sinomenine. Int J Immunopharmacol 16: 685-691. 
Citation: Satoh H (2017) Electrophysiology and Cardiovascular Pharmacology of Mokuboito (Formula Aristolochiae): Cardiotonic and Cardioprotective Actions for Chronic Heart Failure. Cardiolog Res Cardiovasc Med 2: 117. DOI: 10.29011/2575-7083.000017

17. Sato Y, Hanawa T, Arai M (2005) Introduction to KAMPO. Japanese Traditional Medicine, Elsevier Japan KK Tokyo.

18. Chang TM, Chao KC, Lue FH (1958) The mechanism of the hypotensive effect of tentrandrine and demethyltetrandrine. Acta Pharm Sin 8: $163-168$

19. Li DG, Lu HM, Li XH, Quan QZ, Li XM, et al. (1995) Calcium channel blockers in cirrhotic patients with portal hypertension. Chin Med J 108: 803-808.

20. Takemura H, Imoto K, Ohshima H, Kwan CY (1996) Tetrandrine as a calcium antagonist. Clin Exp Pharmacol Physiol 23: 751-753.

21. Dai GZ, Zeng B, Zang YL, Lu YX (1990) Intraveneous tetrandrine in terminating acute episodes of paroxysmal supraventricular tachycardia. Chin Med J 103: 460-463.

22. Lu YS, Wang ZC, Huang WC (1990) Clinical observation on the termination of paroxysmal supraventricular tachycardia by tetrandrine. Chin J Cardiol 18: 164-165.

23. Chen SY, Ye SB (1992) The effects of tetrandrine on metabolism of prostaglandin and lipids in patients with essential hypertension. Clin Pharmacol Bull 8: 436-439.

24. Liang XG, Chang WJ, Zheng DY, Li SC, Fu Y, et al. (1994) Effect of tetrandrine on Lpo, hSOD-1, TXB2, 6-keto-PGF ${ }_{1 \alpha}$ in essential hypertension. J Clin Med Univ 23: 453-455.

25. Nishida S, Satoh H (2009) Pharmacological effects of Mokuboito on cardiovascular and pulmonary systems. Kampo and Current Therapy 18: $297-303$

26. Ezaki H, Inokuchi T, Taniwaki M (2016) Efficacy Mokuboito in patients with severe intractable heart failure. Kampo Med 67: 169-177.

27. Satoh H, Nishida $S$ (2012) Lack of the age-dependent alteration by Mokuboito (Mu-Fang-Yi-Tang) J US-China Med Sci 9: 1-8.

28. Satoh H (2003) Effects of Ginkgo biloba extract and bilobalide, a main constituent, on the ionic currents in guinea pig ventricular cardiomyocytes. Artzmitt Forsh 53: 407-413.

29. Satoh $\mathrm{H}(2001)\left[\mathrm{Ca}^{2+}\right]$-dependent actions of taurine in spontaneously beating rabbit sino-atrial nodal cells. Eur J Pharmacol 424: 19-25.

30. Nishida S, Satoh H (2003) Mechanisms for the vasodilations induced by Ginkgo biloba extract and its main constituent, bilobalide, in rat aorta. Life Sci 72: 2659-2667.

31. Takeda Y, Ward SM, Sanders KM, Koh SD (2005) Effects of the gap junction blocker glycyrrhetinic acid on gastrointestinal smooth muscle cells. Am J Physiol Gastrointest Liver Physiol 288: G832- G841.

32. Daniel EE, El-Yazbi AF, Mannarino M, Galante G, Boddy G, et al. (2007) Do gap junctions play a role in nerve transmissions as well as pacing in mouse intestine. Am J Physiol Gastrointest Liver Physiol 292: G734-G745.

33. Higashida M, Watanabe $\mathrm{Y}$, Hagiwara M, Hiyama $\mathrm{Y}$, Terasawa K, et al (1985) Effects of cinnamaldehyde on the central nerves in reserpinepretreated mices. J Trad Med 2: 244-245.

34. Chen J, Wu Z, Chen S, Gong X, Zhong J, et al. (1999) The effect of tetrandrine on the contractile function and microvascular permeability in the stunned myocardium of rats. Jpn J Physiol 49: 499-506.
35. Liu QY, Karpinski E, Pang PKT (1992) Tetrandrine inhibits both T and L calcium channel currents in ventricular cells. J Cardiovasc Pharmacol 20: $513-519$

36. Lopez-Jaramillo P, Gonzalez MC, Palmer RM (1990) The crucial role of physiological $\mathrm{Ca}^{2+}$ concentrations in the production of endothelial nitric oxide and the control of vascular tone. Br J Pharmacol 101: 489493.

37. Satoh H, Sperelakis N (1991) Calcium and potassium currents in cultured rat aortic vascular smooth muscle cell lines. In Sperelakis $\mathrm{N}$ ed. Ion Channels of Vascular Smooth Muscle Cells and Endothelial Cells. Academic Press, New York: p55-63.

38. Satoh H, Sperelakis N (1995) Modulation of L-type $\mathrm{Ca}^{2+}$ current by isoprenaline, carbachol and phorbolester in cultured rat aortic vascular smooth muscle (A7r5) cells. Gen Pharmacol 26: 369-379.

39. Satoh H (1996) Modulation of $\mathrm{Ca}^{2+}$-activated $\mathrm{K}^{+}$current by isoprenaline, carbachol, and phorbol ester in cultured (and fresh) rat aortic vascular smooth muscle cells. Gen Pharmacol 27: 319-324.

40. Nishida S, Satoh H (2013) Role of gap junction involved with EDHF for the quercetin-induced vasodilatation in rat mesenteric artery. Life Sci 92: 752-756.

41. Kerckhoffs DA, Blaak EE, Van Baak MA, Saris WH (1998) Effect of aging on beta-adrenergically mediated thermogenesis in men. Am J Physiol 274: E1075-E1079.

42. Li G, Li K, Li Z, Wang P (2003) Age-dependent changes in beta-adrenoceptor function in human detrusors and possible mechanisms. Chin Med J 116: 1511-1514.

43. Nishida S, Satoh H (2004) Comparative vasodilating actions among terpenoids and flavonoids contained in Ginkgo biloba extract. Clinica Chimica Acta 339: 129-133.

44. Sugiyama T, Hashimoto K (1989) Chronotropic and inotropic effects of Kampo Extracts in the canine isolated, blood-perfused heart preparations. Jpn J Pharmacol 51: 239-246.

45. Fang DC, Jiang MX (1986) Studies on tetrandrine's calcium antagonistic action. Chin Med J 99: 638-644

46. Huang YT, Cheng YR, Lin HC, Chen SM, Hong CY (1998) Haemodynamic effects of chronic octreotide and tetrandrine administration in portal hypertensive rats. J Gastroenterol Hepatol 13: 266-272.

47. Wang G, Lemos JR (1995) Tetrandrine: A new bligand to block voltagedependent $\mathrm{Ca}^{2+}$ and $\mathrm{Ca}^{2+}$-activated $\mathrm{K}^{+}$channels. Life Sci 56: 295-306.

48. Xie SX, Jin QQ (1993) Prevention of sinomenine on isolated rat myocardial reperfusion injury. Zhongguo Yao Li Xue Bao 14: 12-15.

49. Hojo H, Kondo $\mathrm{Y}$, Umeda H, Taira T, Hashimoto $\mathrm{Y}$ (1985) Effect of sinomenine on antibody responses in mice. J Immunopharmacol 7 : $33-42$.

50. Kupeli E, Kosar M, Yesilada E, Husnu K, Baser C (2002) A comparative study on the anti-inflammatory, antinociceptive and antipyretic effects of isoquinoline alkaloids from the roots of Turkish Berberis species. Life Sci 72: 645-657.

51. Wang Y, Fang Y, Huang W (2005) Effect of sinomenine on cytokine expression of macrophages and synoviocytes in adjuvant arthritis rats. J Ethopharmacol 98: 37-43. 
Citation: Satoh H (2017) Electrophysiology and Cardiovascular Pharmacology of Mokuboito (Formula Aristolochiae): Cardiotonic and Cardioprotective Actions for Chronic Heart Failure. Cardiolog Res Cardiovasc Med 2: 117. DOI: 10.29011/2575-7083.000017

52. Shen YC, Chen CF, Sung YJ (1999) Tetrandrine ameliorates ischemiareperfusion injury of rat myocardium through inhibition of neutrophil priming and activation. Br J Pharmacol 128: 1593-1601.

53. Lou JS, Zhang LL (1988) Effects of propranolol and tetrandrine in combination on epinephrine-induced arrhythmia in rabbits. Acta Pharmacol Sinica 9: 412-415.

54. Satoh H, Sperelakis N (1998) Review of some actions of taurine on ion channels of cardiac muscle Cells and others. Gen Pharmacol 30: 451-463.

55. Yan XH, Li HD, Peng WX (1997) Determination of sinomenine $\mathrm{HCl}$ in serum and urine by HPLC and its pharmacokinetics in normal volunteers. Yao Xue Xue Bao 32: 620-624.

56. Satoh H (2010) Basics of evidences-based herbal medicine. Ed, Satoh $\mathrm{H}$. Research Signpost, Kerala.
57. Satoh H (2013) Pharmacological characteristics of Kampo medicine as a mixture of constituents and ingredients. J Integr Med 11: 11-16.

58. Satoh H (2015) Complemental and alternative medicine for chronic heart failure: Traditional therapy with Kampo medicine. Current Therapy 33: 73-78.

59. Kok TW, Yue PY, MaK NK (2005) The anti-angiogenic effect of sinomenine. Angiogenesis 8: 3-12.

60. Liu ZQ, Chan K, Zhou H (2005) The pharmacokinetics and tissues distribution of sinomenine in rats and its protein binding ability in vitro. Life Sci 77 : 3197-3209. 